This elaborated time-scale has been applied to determining the age of a large number of ruins which have furnished the material from which it has been built up; but perhaps of even greater interest for the archæologist than the dating of individual structures is the precision given to the cultural periods, of which the time relation had been determined previously by archæological methods. For example, the beautiful cream. coloured Hopi ware is seen to begin in the early part of the fourteenth century, the polychrome red pottery largely filled the thirteenth, red pottery was common in the twelfth, and black-on-white ware was characteristic of the tenth and eleventh centuries. In more general terms, of the succession of cultural periods into which archæologists have classified Pueblo civilization, Pueblo III, the golden age of south-western prehistory, took its early form in Chaco Canyon about A.D. 919, reached its local climax in the late eleventh century, and probably closed with the great drought which endured from 1276 until 1299. Pueblo IV began in the early thirteen hundreds. Dating, however, is complicated by the problem of centrifugal diffusion. Pueblo culture, it is thought, probably originated at a single centre, from which it spread outwards. It is not, therefore, everywhere contemporaneous.

So far as the dating of individual ruins is concerned, Pueblo Bonito is now shawn to be the oldest of the south-western ruins. Its building began in A.D. 919, and the major construction took place in the decade 1060-70, with a lesser activity twenty years later. The important site of Aztec, notwithstanding its size, was built in a period of twelve years 1110-21. The dates determined for the beginning of construction on forty-five sites range from A.D. 919 until 1417, except for two instances, dated at 1550 and 1770 respectively.

The investigation has thrown light on a number of collateral problems. For example, there is the question of the former existence in this area of considerable pine forests, which have now disappeared, and by their extinction, no doubt, contributed their share to the aridity of the area. Some specimens which have been examined were evidently dead wood at the time they were used, and the confused and almost indistinguishable rings at the end of their growth bear witness to the aridity which eaused their death. This formation has been paralleled from trees which have died recently.

The evidence of the grouping of sequences of poor growth is interpreted as pointing to a suc. cession of droughts, which recurred with extreme severity at intervals of about three hundred years. One of these droughts, the most severe, covered the closing years of the thirteenth century (1276-99); another appears from 1573 until 1593; and still another in 1890, with a period of maximum intensity from 1896 until 1904. Periods of drought earlier than these are also perceptible, which go back so far as A.D. 904 . The study of these cycles should prove of importance for the future of climatology. Archæologists will look forward with keenest anticipation to the extension of this technique to conditions which will throw light on the beginnings of Pueblo culture and its dating in relation to the culture of the Basket-makers.

\title{
Obituary
}

Mr. R. D. Oldham, F.R.S.

$\mathrm{R}^{1}$ ICHARD DIXON OLDHAM, whose death took place at Llandrindod Wells on July 15, was an original and independent thinker-a little too independent sometimes for those in authority. He was most widely known for his geological work in India and his seismological investigations; but he wrote on other subjects, and his writings are always interesting and suggestive. He was the third son of Dr. Thomas Oldham, F.R.S., the first director of the Geological Survey of India, and was born on July 31,1858 . He was educated at Rugby and the Royal School of Mines, and appears to have been elected to a science scholarship at Emmanuel College, Cambridge, but never took it up. His father, who had retired two years earlier, died in 1878; and he, following his father's footsteps, accepted an appointment on the Indian Geological Survey in 1879.
In the regular fieldwork of the Survey, Oldham had a wide and varied experience, chiefly in the north, ranging from Manipur to Baluchistan; and he also visited the Andaman Islands. The results are to be found in many papers in the "Memoirs" and "Records" of the Survey. In addition to his fieldwork, he edited his father's unpublished papers on earthquakes and thermal springs in India. The most important of these dealt with the Cachar earthquake of 1869 , and the editing included the whole of the discussion of the observations collected by his father, a very useful grounding for his later work in seismology. He also compiled a "Bibliography of Indian Geology" (1888), and prepared the second edition of the official "Manual of the Geology of India" (1893). This was essentially a new work, though it incorporated much of the original edition; and several of the new chapters written by Oldham are of great 
interest to all geologists, not only to those in India. But perhaps his most important work for the Survey was the "Report on the Great Earthquake of 12th June 1897", forming vol. 29 of the "Memoirs" (1900). Seismology was now his chief interest. He was the first to show (Phil. Trans., A, 194, 135) that the disturbance set up by a great earthquake splits into three distinct forms of wave-motion which, travelling at different rates and along different paths, give rise to the three distinct phases observed in distant seismographic records.

Oldham retired from the Survey in 1903 , and for some time lived in the Isle of Wight, where he was near the seismographic station of his great friend, John Milne. His seismological studies were continued; in 1906 he showed that the records of distant earth. quakes indicate that the earth has a core very different in properties from the rest, and he determined its diameter approximately. He was indeed a pioneer in the application of seismology to the investigation of the interior of the earth.

In his later years, Oldham spent much time in the south of France, where he studied the history of the Rhône delta, and finally he withdrew to Llandrindod Wells.

Oldham was awarded the Lyell Medal of the Geological Society in 1908 , and was president of that Society in 1920-22. He was elected a fellow of the Royal Society in 1911.

P. L.

\section{Prof. Snouck Hurgronje}

WE regret to record the death of Prof. Christian Snouck Hurgronje of Leyden, the distinguished authority on the religion and customs of Islam, which took place on June 26 at the age of eighty-one years.

Prof. Hurgronje was not only one of the foremost oriental scholars of his time, but he was also a great exponent of the value in affairs of the study of living native institutions, his intimate knowledge of the languages of the East and of the customs, religion and laws of Islam having proved of signal service to the Colonial Government during his residence in the Dutch East Indies.

Hurgronje was born in 1855 ; and in 1885 was admitted by the University of Leyden to the degree of doctor in Semitic languages and literature for a dissertation on the Feast of Mecca. He continued his oriental studies at Strassburg, and was then appointed instructor in Arabic and the institutions of Islam at the Sehool of Instruction for Dutch-Indian officials at Leyden. In 1884, with the object of obtaining a first-hand knowledge of the religious exercises of Islam, he went to Jiddah, the 'landing place of pilgrims to Mecca. Here he remained until fully equipped to enter the holy places of Mecca. This he did with pilgrims from the Dutch East Indies in February 1885, and remained in the eity until the following August, living with the pilgrims and carrying out their religious observances, until the killing of the French orientalist, Dr. Huber, while trying to penetrate into the interior from Jiddah, led to his expulsion by the Turkish authorities.
In 1889, Hurgronje began his work in the Dutch East Indies, when he was sent out by the Government at The Hague to act as adviser on Moslem institutions in Java. His appointment, originally for two years only, lasted for many years, so valuable did his services prove to the Government. One of his more notable achievements was in tendering advice to the Colonial Government and the Government at The Hague, which was framed in the light of his study of Achinese institutions, and contributed largely to the pacification of northern Sumatra, where the Government had been carrying on a desultory war with the Achinese since 1873.

Although both Cambridge and Leyden had offered chairs to Hurgronje, he declined all such offers until he could regard his work in the East as completed; but he accepted the professorship of Arabic at Leyden in 1906. Here he was not forgetful of his practical experience in the East, and for the remainder of his life he continued to be a close observer of the effect of modern trends in international relations on the development of Islam, a matter upon which he produced several important and authoritative articles. He presided over the Congress of Orientalists when it met at Leyden in 1931, having also been a member of the Congress when it met previously at Leyden in 1883 .

Hurgronje was the author of a large number of contributions to the literature of oriental studies. Among his best-known works are "Mekka" (1888), a study of the Achinese (1893-94), and "Une Nouvelle Biographie de Mohammed"'(1894).

\section{Dr. F. J. F. Shaw, C.I.E.}

Dr. F. J. F. Shaw, whose death in India was recently announced, joined the Indian Agricultural Service in 1910 as a mycologist attached to the Agricultural Research Institute, Pusa. $\mathrm{He}$ remained at Pusa for the whole of his service except for a short period at Coimbatore in Madras, and was engaged in research in plant pathology and work on the control of plant diseases until 1928, when he was appointed Imperial economic botanist. Even in this latter appointment much of his work was the breeding of crop plants for resistance to disease, so that he retained his interest in plant pathology in the broad sense. Of late, much of his time was occupied in administrative duties, for he was appointed director of the Imperial Institute of Agricultural Research at Pusa in 1934, and as such had the supervision of the arrangements for transferring the Institute, wrecked by the Bihar earthquake that year, to a new site near Delhi. For the last few months he was at Simla officiating as agricultural expert with the Imperial Council of Agricultural Research ; but he left to supervise some of the difficult operations of the transfer of the Institute, and was overcome by the heat at Agra.

Dr. Shaw was best known for his researches on the important fungal parasites of Indian crops belonging to the genus Rhizoctonia, and for his studies on the diseases of jute and the control of diseases of 